\title{
An Investigation of How the Partnership for 21st Century Framework Reflects Innovation in MBA Programs
}

\author{
Lacey R. Finley \\ Park University \\ Karla Saeger \\ University of Wisconsin-Whitewater \\ Molly J. Wickam
Bethel University
}

There is lack of understanding about effective teaching methods for innovation education in business schools and programs. A non-experimental, descriptive study of American ACBSP-accredited business schools and programs was designed to survey MBA program leadership. MBA programs are offering innovation education but it is limited to courses and not entire concentrations; MBA programs are using experiential learning approaches to teach innovation; and, communication and collaboration were the top instructional strategies used. MBA programs should consider developing coursework focused on innovation education. The 4Cs outlined in the Partnership for $21{ }^{\text {st }}$ Century Skills should be explicitly taught within the MBA.

\section{INTRODUCTION}

Since the first Master of Business (MBA) program began in the early years of the 20th century it has been continually evolving its curriculum to meet the needs of globalization change. This advanced professional degree has traditionally been linked to job security and increased salary, but it is also connected to developing knowledge and skills associated with managerial positions. To ensure quality programs, higher education institutions have the availability to seek accreditation. Accreditation is a rigorous, external, quality assurance process that requires the institution to meet a set of quality standards. One such accreditation is the Accreditation Council for Business Schools and Programs (ACBSP) which is a global business education accrediting body and the first organization to offer accreditation to all levels of collegiate business education degree programs.

The ACBSP was founded in 1988 and developed a set of standards and criteria that provides a framework for graduate business schools to achieve excellence in business education programs. The ACBSP is governed by 20 principles that ensure accountability and academic improvement. One principle is committed to "creating an environment that supports innovation and experimentation" (ACBSP, n.d., p. 4). ACBSP defines how innovation is used throughout the standards and criteria of accreditation: 
The term "innovation" refers to making meaningful change to improve programs, services, and processes and to create new value for students and stakeholders. Innovation involves the adoption of an idea, process, technology, or product that is either new or new to its proposed application. Successful organizational innovation is a multi-step process that involves development and knowledge sharing, a decision to implement, implementation, evaluation, and learning. Although innovation is often associated with technological innovation, it is applicable to all key organizational processes that would benefit from change, whether through breakthrough improvement or change in approach or output. (ACBSP, n.d., p. 60)

The Association to Advance Collegiate Schools of Business (AACSB) is another business school accreditation. Established in 1916, AACSB provides quality assurance to business education. The organization's mission is to foster engagement, accelerate innovation, and amplify impact in business education (AACSB, 2013). In 2020, the AACSB launched a new set of standards with a specific focus on innovation included in Standard 1 Strategic Planning and Standard 4 Curriculum. Within the Curriculum Standard it is noted that innovation must exist in the curriculum with respect to content, pedagogy, or delivery (AACSB, 2020, p. 40).

Innovation skills in one essential skill developed in current MBA programs others include communication skills, and both analytical and strategic thinking skills (Berdan, 2012). While many of these skills have seen positive growth in U.S. higher education institutions, (Brill, Gilfoil, \& Doll, 2014; Gupta \& Bennett, 2013; Iyengar, 2015) innovation has been identified as an area that business schools need to provide a deeper understanding (Datar, Garvin, \& Cullen, 2011). Sullivan (2011) agreed, "most business schools do not directly incorporate innovation into their own unique missions and operations - they do not capture, articulate or overtly implement this central contribution to society" (p. 492). Therefore, it is not surprising that innovation is included in both the ACBSP and the AACSB accreditation standards considering the importance innovation plays in the global economy.

Concerns regarding teaching innovation at the university level are not new. Enarson and Drucker (1960) explained the contradiction between how colleges and universities have been credited with being a major force of innovation in American life and economy with the "curiously resistant - even hostile - to innovations attempted within the university" (p. 495). Examining how innovation is developed in today's MBA programs, Kars-Unluoglu (2016) suggested, "the teaching mode in leading business schools appears to be moving further towards a mode that is more explorative in nature and collaborative in style" (p. 89). Building on this premise, Seidel, Marion, and Fixson (2020) analyzed four modes of teaching the innovation process to business students. The teaching modes included design thinking, focused inquiry, new perspectives, and emerging trends. Ultimately, the findings emphasized that all four modes of teaching innovation are important and may contribute to the "development of individuals who are better able to develop both breadth of experience and depth of understanding of topics important for careers in which innovation may play a central role" (p. 82).

Beyond methods of teaching innovation, innovation education has recently emerged as a new academic field in higher education. Fagerberg and Verspagen (2008) explained "how the development of innovation studies as a scientific field is part of a broader trend towards increased diversification and specialization of knowledge that blurs traditional boundaries and challenges existing patterns of organization within science (including social science)" (p. 218). The study of innovation has been identified as "a strategic response to managing in a knowledge-driven competitive environment" (Kars-Unluoglu, 2016, p. 74) and can be a catalyst for innovation education not only within business schools but across all disciplines of the university.

The ability to create and implement innovation is a driving competitive advantage of the business industry and a contributor to the development of global economies (Fagerberg, Mowery, \& Nelson, 2005). Therefore, it is not unexpected that recent studies have investigated how innovation is being cultivated in business schools (Kars-Unluoglu, 2016; Fischer, Dietz, \& Antonakis, 2017; Eason, Mazzei, \& Service, 2019; Priem, 2018; Seidel, Marion, \& Fixson, 2020). Yet, researchers have identified a significant gap in 
the development, teaching, and assessment of innovation education (Kars-Unluoglu, 2016; Maritz et al., 2014).

\section{PURPOSE AND RESEARCH QUESTIONS}

Previous research indicates that there is a lack of understanding about the content and process of innovation education (Kars-Unluogla, 2016), and while business schools have begun to focus on innovation education, there is a lack of consensus as to how it should be taught (Cousens et al, 2009). At the same time, there is repeated evidence of a gap between what employers want business graduates to have and what business schools and programs teach (Bhardwaj et al., 2018). For example, a PayScale Inc. survey found that $50 \%$ of employers say college graduates are "lacking in interpersonal skills, problem solving, effective writing and oral communication, and the ability to think critically and analytically" (Friedman, 2017, p. 21).

Universities are being asked to incorporate the teaching of innovation into the curriculum if they want to remain relevant in the 21st century (Eason \& Mazzei, 2019). Yet, "the best way to promote and develop these skills for innovation within the education system remains unclear" (Cobo, 2013). Given this lack of understanding and consensus surrounding the role of innovation education in business schools and programs, the purpose of the study was to understand how American MBA programs are teaching MBA students about innovation education. There were two research questions:

\section{RQ1: To what extent are American MBA programs offering innovation education?}

RQ2: What curriculum approaches do MBA program leaders report are being used to develop innovation in their programs?

\section{THEORETICAL FRAMEWORK}

The theoretical framework for the present study is P21's Frameworks for $21^{\text {st }}$ Century Learning, a framework developed by the Partnership for $21^{\text {st }}$ Century Skills $(\mathrm{P} 21,2011)$. This organization was founded by partnering with education, business, community, and government leaders. Founding members included Cisco Systems, Inc., Dell Computer Corporation, Microsoft Corporation, and the United States Department of Education (Kivunja, 2014). The P21 Framework for $21^{\text {st }}$ Century Learning defines the skills and knowledge needed for success in work and life, puts $21^{\text {st }}$ century skills at the center of learning. One of the domains of skills, the Learning \& Innovation Skills part of the framework, describes the 4Cs: critical thinking and problem solving, communication, collaboration, and creativity \& innovation (P21, 2015). The innovation part of the 4Cs is defined as the ability to "act on creative ideas to make a tangible and useful contribution to the field in which the innovation will occur" (P21, 2015, p. 4).

The P21 Framework is grounded in the belief that all students should be provided the opportunity to develop 21 st century skills in order to succeed in a global world. The P21 Framework is equally important at all educational levels and innovation specifically has emerged as the "essential means to positively impact society" (Sullivan, 2011, p. 493). Business schools and specifically MBA curriculum must develop students' ability to implement innovative change within the organization. Therefore, the P21 Framework influenced this study to investigate what curriculum approaches are used to develop innovation skills in MBA programs.

\section{REVIEW OF THE LITERATURE}

With the 4Cs in mind, a review of existing literature was conducted to gain background knowledge useful in solving the research questions. Literature surrounding existing innovation education in MBA programs was conducted. Literature surrounding curricular approaches in innovation education, especially in specific MBA courses such as entrepreneurship, marketing, technology management, and strategy, was 
also explored, though it is limited. In addition, literature surrounding current methods of teaching innovation education was reviewed, and instructional strategies used to teach innovation were explored, especially when literature related to the $4 \mathrm{Cs}$ could be found.

\section{Existing Innovation Education in MBA Programs}

Published literature on existing innovation education in business schools and programs is scant. Fish and Kim (2013) outlined the entrepreneurship major at Canisius College. This major, which draws on management, marketing, and finance, consists of seven courses that specifically prepare students to start a new business, acquire an existing business, manage an existing business, or engage in intrapreneurship. A stated goal of the program is to "foster creativity and innovation in the business school" (p. 483). The key components for how this is accomplished include learning and developing processes for developing products and services; developing communication skills; participating in real-world learning experiences; and business planning.

Northwestern University's Kellogg School's MBA identified four strategic initiatives as essential for an MBA graduate's future success. The four were: collaboration; innovation \& entrepreneurship; markets $\&$ customers; and, public/private interface. Together, these four strategic initiatives were viewed as the lens by which the functional areas of business such as marketing, economics, operations, and management would be taught ("What innovation," 2016). Researchers interviewed 30 deans from high-ranking US and European MBA programs and identified eight common needs of these programs. One need is for programs to think both creatively and innovatively. This is described as being able to collect, synthesize and distill large volumes of data, engage in experimentation, and find problems that need to be solved (Howard, Datar, Garvin \& Cullen, 2011).

An MBA course focused on management education for innovation (the name of the course was not given) in Barcelona, Spain, had as a stated goal to build innovation capacity in its students. Case studies, exercises, and a final hands-on group project were the methods used in this course. Students were asked to keep diaries, and at the end of the course, the diaries were analyzed. One of the findings was that innovation capacity was increased, but researchers admitted that additional research needs to be done to validate that the capacity for innovation can be increased in an MBA course (Ivanova, 2016).

\section{Methods of Teaching Innovation Education}

Research is quite limited as to the curricular approaches business education is using to teaching innovation. Thomas (2014) argued that there should be, "urgency of curriculum reform and the radical rethinking of management education paradigms and philosophies in an innovative, technologically driven economy" (p. 59). A review of the literature found that existing methods in innovation education include project-based learning, experiential learning, design thinking, and the case study method.

\section{Project-Based Learning}

Project-based learning (PjBL) is an instructional strategy derived from the theory of social constructivism (Bruner, 1966; Dewey, 1929; Vygotsky, 1978). In PjBL, knowledge is constructed within a social learning experience which allows the use of multiple perspectives (Duffy \& Cunningham, 1996; Grennon-Brooks \& Brooks, 1999). Criteria for PjBL include focusing on problems that allow students to struggle with major concepts, are student-driven, realistic, authentic, highly-related to curriculum goals, and allow students to work together (Thomas, 2000). PjBL is closely related to experiential learning in that both use investigation and reflection as central concepts in learning, and both are rooted in social constructivism (Grennon-Brooks \& Brooks, 1999; Kolb, 1984). As a student-centered instructional approach, PjBL has been shown to enhance the ability to work effectively on a team, communication skills, presentation skills, and critical thinking (Neo \& Neo, 2009).

In business education, $\mathrm{PjBL}$ often uses authentic, hands-on ways of finding and solving a problem. In a study of syllabi gathered from 29 MBA programs that offer at least one course on innovation education, class participation ( $67 \%$ of the sample) and a group project ( $74 \%$ of the sample) were the two most common assessments, with a higher percentage of overall course grade weighted on the group project. Examples of 
group projects included solving a real-world business problem for a business, competitive design projects where student groups competed against each other, design projects for real businesses, and consulting projects for companies (Kars-Unluogla, 2016).

\section{Experiential Learning}

Experiential learning theory is rooted in Dewey (1938), who believed learning through experiences was the starting point of the educational process. The most widely used experiential learning model is Kolb's (1984) four-step learning model, where "learning is the process whereby knowledge is created through the transformation of experience" (p. 26). There are four steps in the experiential learning model: concrete experience, reflection on the experience, synthesis and abstract conceptualization, and active experimentation. In the concrete experience stage, activities such as fieldwork, practicums, or service are performed by students. Reflection, the second stage, involves self-analysis of the experience, and can come in the form of written assignments (Bisman, 2011; Mabry, 1998), discussion (Mabry, 1998), and written end-of-course exams (Dubinsky, 2006). Literature confirms repeatedly that reflection is key to any successful learning methodology that involves experiences (Dewey, 1933; Dubinsky, 2006). In the abstract conceptualization stage, students analyze ideas and observations of their experiences, and in the active experimentation stage, students act out what they have learned.

One experiential learning course called Innovation Boot Camp was assessed using a mixed-methods approach to learn to what degree students improved their creative thinking potential by participating in the boot camp. The 93 participants were undergraduate engineering or design majors in their junior or senior year. The boot camp used a process to teach principles of innovation. The first stage was idea finding, where participants found a service, system or product to create or modify. The second stage was idea defining, where a problem needing to be solved was defined. The third stage was idea communicating, where prototypes were mocked and tested with stakeholders such as peers and professionals from the marketplace (West, Tateishi, Wright \& Fonoimoana, 2012).

To assess the Innovation Boot Camp, the Torrance Tests of Creative Thinking was used as a pre-and post-test. Scores increased and the increases were significant, leading researchers to believe that the boot camp improved creative thinking potential. Since the boot camp was a short, two-day experience, more research is needed to see if those improvements in creative thinking would be sustained over time and whether results could be replicated (West, Tateishi, Wright \& Fonoimoana, 2012).

\section{Design Thinking}

Design thinking has emerged as a method used to teach and foster innovation (Biffi, Bissola \& Imperatori, 2017), and business schools and programs have only recently started integrating design thinking into their curriculums. According to Razzouk and Shute (2012), design thinking is defined as "an analytic and creative process that engages a person in opportunities to experiment, create and prototype models, gather feedback, and redesign" (p. 330). CaseWestern Reserve University's Weatherhead School of Management redesigned its MBA program to build design thinking, or what they named managing-asdesigning, into the heart of the program (Cooperrider, 2008).

There is published research calling for designing thinking in business schools, but there is little research that assesses the results of design thinking in business schools (Glen, Suciu \& Baughn, 2014). One exploratory case study on assessing design thinking as a method of teaching the skill of innovation was conducted by asking students in an undergraduate Product Development course to develop a product line for a local small business. Design thinking gave students a process by which to guide them through a process that would help them solve the client's problem. In assessing how the course went, students struggled with conflict resolution and communicating with their teammates in constructive ways that would further the process (Foster \& Yaoyuneyong, 2016).

Glen, Suciu, and Baughn (2014) have called on business education to offer coursework using design thinking at both the undergraduate and graduate levels, saying it could be offered as a stand-alone course or integrated into functional business courses. In addition, some design schools and business schools have begun collaborating (Cooperrider, 2008). The Institute of Design at Stanford University has refined its 
design thinking teaching methods over the years and now offers a Design Thinking Bootleg set of tools and resources so that others can use design thinking in workshops or courses. The design thinking process they use consists of five modes: empathize, define, ideate, prototype, and test (Plattner, 2010).

Design thinking is an active learning method and aligns well with Kolb's (1984) experiential learning theory. Three professors described a design thinking exercise used in undergraduate courses with 20-30 students in each course. The exercise was conducted using a Personal Application Assignment worksheet which used Kolb's experiential learning cycle. The output for students was a written reflection of the design thinking exercise and the learning activity on which it was based (Stock, Bucar \& Vokoun, 2018).

\section{Other Methods of Teaching Innovation Education}

Curricula involving innovation is likely to include a mix of several curricular approaches (O'Sullivan, 2003). Other curricular approaches to innovation education that are non-experiential in nature exist, although research about them is limited. The case study method is used in innovation education. The case method was heavily adopted for use in business courses in the early 1900s by the Harvard Graduate School of Business. In this instructional method, problems from real businesses are presented to students, who use business concepts to build their knowledge (Alstete \& Beutell, 2016).

In a study of syllabi gathered from $29 \mathrm{MBA}$ programs that offer at least one course on innovation education, the case study method was the most used, with 19 out of 29 courses using at least one case. Of these 19 courses, 54\% used cases published by Harvard Business Review. Of the Harvard Business Review cases, the most popular was titled IDEO Product Development, and it was used in four of 19 courses (KarsUnluogla, 2016). An innovation management course that focused on project-based learning also used case studies to deliver some of the course content, and the final deliverable of the project was a written case study (O'Sullivan, 2003). The case study method of instruction has been criticized by business professors seeking to teach innovation skills in business courses as outdated, and part of a paint-by-numbers way of teaching, because reading and analyzing cases does not mimic innovation as it is done in the business world (Eason, Mazzei \& Service, 2019).

Another method is the use of guest speakers to supplement topics about innovation. In a study of syllabi gathered from 29 MBA programs that offered at least one course on innovation education, 14 of the 29 courses had industry professionals, including entrepreneurs, serve as guest speakers (Kars-Unluogla, 2016). This same study found that online simulations, workshops, class exercises, and textbooks were used to teach innovation. Textbooks were only used in 2 out of 29 courses, with other courses using readings such as book chapters and journal articles. When looking at assigned readings, the most assigned reading was Connect and Develop: Inside Procter \& Gamble's New Model for Innovation (Larry \& Sakkab, 2006), and that reading was assigned in 7 out of 29 courses (Kars-Unluogla, 2016).

\section{Instructional Strategies}

Existing literature surrounding instructional strategies used in innovation education in MBA courses was sought, using the $4 \mathrm{Cs}$ framework from our theoretical framework.

\section{Collaboration Skills and Communication Skills}

P21 (P21, 2015) defines collaboration as the ability to work effectively and respectfully with diverse teams; flexibility and helpfulness; shared responsibility, and the ability to value individual contributions made by members of the team. Trilling and Fadel (2009) suggested that in order to achieve successful collaboration, students should be taught to work with diverse people, in diverse contexts (physical and online workspaces), flexibility, compromise, and personal responsibility for achieving tasks that contribute to the team goals. Valuing the individual and joint contributions of each team member is another important part of collaboration.

Collaboration has been shown to be enhanced when students are involved in project-based learning. Solving problems in a group setting can help students learn how to work with others, communicate, and resolve conflicts (Tamim \& Grant, 2013; Winter, Neal \& Waner, 2005). In the $21^{\text {st }}$ century workplace, and even more during the 2020-2021 COVID-19 pandemic, people are working with others they may have not 
ever physically met, in virtual environments using new technologies such as Zoom and Google Hangouts, to accomplish common tasks.

According to P21, "communication skills have always been valued in the workplace and in public life. But in the 21st century, these skills have been transformed and are even more important today" (P21, 2014, p.13). There are five sets of communication skills in the P21 framework: the ability to articulate thoughts and ideas effectively in both oral and nonverbal ways; listening; the ability to utilize communication effectively; the ability to use media and other communication technologies; and, the ability to communicate in different environments (P21, 2015)

Trilling and Fadel (2009) suggested several approaches to effectively teaching the P21 communication skills. Students should articulate their ideas using oral, written, and nonverbal communication, and these skills should be taught in many different contexts. Students should engage in active listening, and consider a variety of cultural backgrounds in doing so. Students should use a variety of technologies to communicate. A study of business managers (Shuayto, 2013) was undertaken to see whether business leaders believed MBA programs prepared students. Findings showed that the top three skills prospective employers said needed to be obtained by business graduates were responsibility and accountability, interpersonal skills, and oral communication skills.

Closely related to communication skills are interpersonal skills, defined as the ability to understand and interact effectively with others (Gardner, 1983). A study of corporate human resource managers or directors was conducted to determine the skills and abilities prospective employers of entry-level business graduates desired (Tanyel et al., 1999). Employers ranked (in order) interpersonal skills, ethical values, and responsibility/ accountability. Porter \& McKibbins (1988) asked corporate college recruiters which skills should be taught in MBA programs and found that corporate college recruiters listed leadership/interpersonal skills, business knowledge, and high motivation to work as the top three attributes they were looking for when recruiting MBAs. Segon \& Booth (2012) sought to find out what gaps existed between MBA programs and actual managerial practice, as perceived by business managers. Results showed that the top three skills managers believed graduates were lacking were emotional intelligence, communication skills, and interpersonal skills/dealing with others.

\section{Decision-Making and Problem Solving Skills}

Decision-making is the ability to consider a variety of alternatives and make a choice ("Secretary's Commission," 1991). Bhardwaj et al. (2018) criticized strategy courses and business curriculum in general, saying business schools continue to fall short teaching unstructured problem solving skills and decisionmaking skills. Decision-making skills are closely related to problem solving skills, which are closely aligned with critical thinking skills. The P21 framework $(\mathrm{P} 21,2014)$ combines the skills of critical thinking and problem solving into one of its 4Cs domains. P21 define critical thinking and problem solving as reasoning, using systems thinking, making decisions, and solving problems. Furthermore, P21 (2015) defines the skill of solving problems as the ability to: "solve different kinds of non-familiar problems in both conventional and innovative ways; and, identify and ask significant questions that clarify various points of view and lead to better solutions" (p. 4). Trilling and Fadel (2009) suggested that teaching problem solving processes is an important part of $21^{\text {st }}$ century skills and suggest several approaches to teaching critical thinking and problem solving skills. These include teaching the ability to reason, use systems thinking to analyze how parts of a whole work together, teach the ability to use data and good judgment to evaluate alternatives, and then make rational decisions.

Stanford University offered a course in its MBA titled Creating Infectious Action. The course used design thinking to have teams prototype problems and discover solutions (Howard, Datar, Garvin \& Cullen, 2011). A longitudinal study (Levy \& Murnane, 2004) was conducted from 1960-2000 of competencies needed in a knowledge economy. Researchers developed an expert thinking profile of skills and described the desired traits as creativity, communication, collaboration, and problem solving. A sample of BusinessWeek readers or senior executives who work for companies with 1,000 or more employees were asked for recommendations of how business schools could prepare graduates with the skills of innovation and creativity. Recommendations included having them innovate in teams, coursework in innovation, 
partner students and businesses together to solve real problems, allow students to fail and fail fast, teach students how to take risks (Vardis \& Selden, 2013).

\section{Innovation Education in Business Coursework}

Literature was reviewed to help uncover which MBA courses are teaching innovation and closelyrelated skills. Although some marketing and entrepreneurship courses are teaching these skills, there was not one functional area of business that emerged as leading the way in teaching innovation skills.

\section{Marketing}

A new Marketing/Management interdisciplinary course on Technology and Innovation Management was designed as an MBA elective course with the following course objectives: "(1) defining technology and innovation, (2) understanding how to shepherd scientific and technical concepts through the innovation process to the marketplace, (3) exploring the challenges of marketing technology-based innovations, (4) identifying the components of technology strategy and explaining how technology strategy relates to the overall business strategy, (5) exploring the role of culture in managing technology and innovation, and (6) understanding the legal and ethical dimensions of technology and innovation management" (Athaide \& Desai, 2005, p. 241). Student course evaluations were analyzed to assess perceptions of their academic learning on a Likert-style scale of $1=$ nothing at all, $5=$ a lot. Results showed a mean score of 4.66 out of 5 (Athaide \& Desai, 2005).

A study assessed two undergraduate courses; Creative Marketing (for marketing majors) and Product Development (for fashion merchandising majors). The courses used a joint client-based project where students from both courses collaborated on a project, and the goals of this were to strengthen students' communication and collaboration skills. The authors noted that collaborative communication increased from the beginning to the end of the course. Other skills that increased were conflict resolution skills, the ability to see multiple perspectives within their project teams, and the ability to brainstorm more quickly. Students reported that the client-based project improved their ability to be creative and innovative and strengthened their communication and collaboration skills (Foster \& Yaoyuneyong, 2016).

\section{Technology Management}

As found in the Technology and Innovation Management course (Athaide \& Desai, 2005), there is a need for integration between technology concepts and innovation. In that same MBA course, The Innovator's Dilemma: When New Technologies Cause Great Firms to Fail (Christensen, 1997) was assigned reading. An exploratory study (Kars-Unluoglu, 2016) that analyzed 29 innovation courses at 20 business schools found that $59 \%$ of the courses contained technology-related topics like university-industry technology transfer, user hacking, and user innovation.

Georgia Institute of Technology and Emory University developed a program titled Technological Innovation: Generating Economic Results (TI:GER $®)$ that combined full-time science and engineering $\mathrm{PhD}$ students with full-time JD and MBA students into a program focused on technology commercialization (bringing technology-based products to market). The justification for combining law and business students who had career goals in technology or innovation management was that they need to understand the intersections between technology, business, and law. Students from these three degree programs worked together on a project related to the PhD students' research. All students in the TI:GER ${ }^{\circledR}$ program take Fundamentals of Innovation I and Fundamentals of Innovation II in the first year of the program. Technology topics in those courses include university-industry technology transfer and identifying entrepreneurial opportunities in technological environments (Thursby, Fuller, \& Thursby, 2009).

\section{Management and Strategy}

Published research is scant on innovation skills taught in management or strategy courses. Bhardwaj et al. (2018) are critical of strategy courses and business curriculum in general, saying business schools continue to fall short teaching unstructured problem solving skills and decision-making skills. They are also critical of textbooks used in strategy courses, saying they do not reflect the uncertainty and ambiguity that 
real strategy-making involves. Eason et al. (2019) are critical of today's MBA strategy courses and call for them to require critical thinking and innovations, acknowledging that it is much more difficult to write curriculum that meets these goals because strategic plans must change frequently and adapt to current and ever-changing situations. Priem (2018) calls on strategy teachers to forgo frameworks they used in the 1980s and 1990s and instead teach processes that help students improve their critical thinking.

\section{Entrepreneurship}

Historically, innovation education was a subset of entrepreneurship education, with Drucker (1985) taking the lead in intertwining the two disciplines. Until recently, entrepreneurship curricula has been the curricula used to promote the development of innovation/innovation capacity, and innovation education was not its own discipline. Fortunately, the conversation about innovation education has changed over the past couple of decades, from whether or not innovation could be taught to how universities can best develop innovative capacity in students (Mayhew, Selznick, Zhang et al., 2019).

Terms innovation and entrepreneur are commonly used interchangeably, but this is outdated. While the two terms are closely connected, innovation has been described as a tool for the entrepreneur (Mirela, 2008). Glassman and Opengart (2016) found enough support in existing literature to view innovation entrepreneurship and innovation as stand-alone concepts. Maritz and Donovan (2015) have tried to distinguish the two disciplines by stating that entrepreneurship relates to the discovery, evaluation and exploitation of opportunities in the process of business start-up, creation and growth, while innovation "relates to the development, adoption and exploitation of value-added activities in economic and social areas" (p. 74).

A 2007 national study of undergraduate seniors from five US universities explored innovative entrepreneurship to gain insights into the learning experiences that increased innovative entrepreneurial intentions in undergraduate seniors. While the literature on entrepreneurship education is well-established (Mayhew et al., 2012), literature on innovative entrepreneurship is very limited. An innovative entrepreneur "provides a new product or service or ... develops and uses new methods to produce or deliver existing goods and services at lower cost" (Baumol et al. 2007a, p. 3). Findings indicated that educational practices that influenced innovative entrepreneurial intentions were having students problem-solve and having the students construct and defend an argument. The sample contained students from various majors, and an interesting finding was that business majors were significantly more likely to express their innovation intentions than majors associated with health or education (Mayhew et al., 2012).

\section{RESEARCH DESIGN AND METHODOLOGY}

The research design for this study was a non-experimental, descriptive study. The quantitative method was survey research. IRB approval was obtained from all three of the researchers' universities. The population of interest was the leadership of US MBA programs. The chosen sample was program directors/coordinators of ACBSP-accredited MBA programs based in the United States, and this sample was chosen because MBA program leadership is the common thread that connects faculty, students, employers with innovation education.

The sampling frame was a list of 162 ACBSP-accredited MBA programs, which is publicly available. Non-probability sampling was chosen and the self-selection technique of allowing the sample to express their desire to take part in the research process was used. While names of MBA programs are publicly available, names and email addresses of program directors/coordinators who work in those programs are not publicly available so were sought via Google searches. When Google searches did not return the information, phone calls were made to the university.

The measure used to answer the research questions was a self-administered survey. Survey questions were developed using the review of the literature. To pre-test the instrument, a pilot of the survey was conducted with MBA faculty and former MBA program directors/coordinators outside of the proposed study population, and these participants were asked to confirm question clarity and the amount of time it took to complete the survey. The survey items were modified according to suggestions from the 
participants. Content validity and face validity of the instrument were confirmed through the literature review, the instrument's pre-test, and the researcher's expertise (Gall, Gall, \& Borg, 2007).

Using the Qualtrics survey tool, one email, with an invitation to participate, an informed consent, and a link to the survey, was emailed to each person in the sample. A second and final reminder email was emailed two weeks later, and participants were asked not to take the survey a second time if they had already taken it. Of the sample of 162,31 responded, for a response rate of $19 \%$. In keeping with the descriptive research design, descriptive statistics in the form of frequency distributions, percents, and means were used to analyze the data.

\section{RESULTS}

The first research question addressed to what extent American MBA programs are offering innovation education. Most of the MBA programs (73.68\%) reported being part-time programs, and a majority of the survey respondents (61\%) were from universities with fewer than 200 students in their MBA programs. University enrollment is summarized in Table 1 (see Appendix A). Results showed that $54 \%$ of universities surveyed have at least one course specifically devoted to teaching about innovation. However, an overwhelming majority (79\%) of universities surveyed do not offer a concentration/certificate/emphasis (12 credits or more) in innovation. The relevant survey questions are provided in Table 2.

The second research question explored the curriculum approaches MBA program leadership is using to develop innovation in MBA programs. The topic of innovation is most explicitly integrated into entrepreneurship courses (93\%) followed by a three-way tie of marketing $(80 \%)$, strategy/strategic management $(80 \%)$, and technology $(80 \%)$ courses. Courses with the topic of innovation most explicitly integrated are summarized in Table 3.

The top four innovation instructional strategies used in coursework were communication with others $(11 \%)$, collaboration/working with others (10\%), independent decision-making (9\%), and solving hypothetical problems $(9 \%)$. The innovation instructional strategies are summarized in Table 4 . The top two methods used to teach the skill of innovation were experiential learning (23.5\%) with 4 of 17 selecting it as \#1 and team project-based learning with a real organization $(23.5 \%)$ with 4 of 17 selecting it as \#1. The methods used to teach the skill of innovation are summarized in Table 5. Additionally, 52\% of MBA program leadership reported that their programs used principles of design thinking to teach innovation (see Table 6).

\section{Discussion}

There are three findings in the present study, and the findings lead to recommendations. The first finding answers the question, To what extent are American MBA programs offering innovation education? MBA programs are offering innovation education, but in a limited way, with the majority offering a course, but not a concentration or emphasis, specifically devoted to innovation. This finding partially confirms the literature review, which found that some marketing and entrepreneurship courses are teaching innovation skills, but overall, there is not one functional area of business that emerged as leading the way in teaching innovation skills. In 2006, The Center for Business Innovation and Creativity at The Coles College of Business found that fewer than $10 \%$ of MBA programs who responded to a survey had any type of course that contained innovation education, and less than $30 \%$ of MBA programs had at least a two-hour module addressing innovation (as cited in Vardis \& Selden, 2013).

Limited research has addressed reasons why innovation is not being taught in MBA programs. One study found that the curriculum is already too full and there is not room to add innovation education (Vardis $\&$ Selden, 2013). Additionally, few faculty who research innovation have received training, through their doctoral programs, on how to teach innovation, there is lack of agreement among scholars as to what should be taught and how it should be taught (Kars-Unluogla, 2016). Additionally, faculty may not be innovative enough to teach innovation (Vardis \& Selden, 2013), and lack of funding to fund programs on innovation is a possible barrier to including innovation in curriculum (Vardis \& Selden, 2013). 
A recommendation, based on the finding, is that business schools and programs that have not yet developed coursework focused on innovation education should consider doing so. There is some support surrounding the idea of integrating innovation curriculum into short-duration courses or experiences. Innovation curriculum may not need to be a major or a minor or even a course in order to help business students increase their innovation capacity (Mayhew, Selznick, Zhang et al., 2019).

Another recommendation is that as MBA programs evolve, those who have found success in offering innovation education may wish to add additional offerings on innovation topics. "Designing multidisciplinary concentrations (or minors) and modalities are helpful in allowing students to specialize in their area of interest (i.e., research, innovation, consulting, entrepreneurship, and social leadership development)" (Khan \& Law, 2015, p. 71). AACSP International explicitly calls for business schools to advocate for their role in innovation (AACSB International, 2010), and ACBSP defines learning as "new knowledge or skills acquired through evaluation, study, experience, and innovation" ("ACBSP Unified Standards," p. 61).

An additional recommendation is that graduate business programs collaborate with undergraduate business majors, and vice versa, to develop and implement coursework about innovation. Professors who assessed a new MBA marketing/management course titled Technology and Innovation Management recommended that what they learned from researching their course could be implemented by faculty from similar traditional undergraduate majors, and they offered suggestions for adapting a three-weekend MBA course tailored to working adults to a more traditional 15 -week course for traditional undergraduates (Athaide \& Desai, 2005). MBA programs could also collaborate with the teacher education faculty at their institutions to help them learn new pedagogies required to teach innovation, as was suggested by an entrepreneurship program in Pakistan (Shaheen, Ahmad, \& Hussain, 2019). Researchers of the top 50 US MBA programs suggested training individual faculty to think more integratively to avoid being siloed within their own academic disciplines (Navarro, 2008).

A second finding seeks to answer the research question, What curriculum approaches are MBA program leadership using to develop innovation in MBA programs? The top two methods used to teach the skill of innovation were experiential learning (23.5\%) and team project-based learning with a real organization (23.5\%). Additionally, 52\% of MBA program leadership reported that their programs used principles of design thinking to teach innovation. This shows that MBA programs are using experiential learning approaches to teach concepts related to innovation.

A recommendation is for MBA programs to consider adding design thinking methods to curricula. Design thinking has emerged as a method used to teach and foster innovation (Biffi, Bissola \& Imperatori, 2017), and business schools and programs have only recently started integrating design thinking into their curriculums. As of 2009, Stanford University offered a course in its MBA called Creating Infectious Action. The course used design thinking to have teams prototype problems and discover solutions (Howard, Datar, Garvin \& Cullen, 2011). CaseWestern Reserve University's Weatherhead School of Management redesigned its MBA program to build design thinking, or what they named managing-as-designing, into the heart of the program (Cooperrider, 2008). If business schools and programs do incorporate design thinking into their curricula, they will then need to assess its effectiveness, as there is little research that assesses the results of design thinking in business schools.

A third finding involves instructional strategies. The present study found that communication with others and collaboration/working with others were the top instructional strategies. This aligns well with the Learning \& Innovation Skills part of the P21(2015) framework which describes the 4Cs: critical thinking and problem solving, communication, collaboration, and creativity \& innovation. A recommendation is for program leaders to encourage faculty to seek professional development that will help them learn more about communication and collaboration skills, and in turn, learn new pedagogies that will help them teach these skills. The $4 \mathrm{Cs}$ need to be explicitly taught and it should not be assumed that they will be learned by relying on experiences that students might have in their coursework (Kivunja, 2014). 


\section{Limitations}

By choosing to study program leadership at ACBSP-accredited institutions, the results of the study are limited in its generalizability. Enlarging the sample to include additional business schools, including schools with other accreditations, would allow for the findings to be further explored. Similarly, this study's focus was on graduate business students, so it may not be generalizable to undergraduate business students. Furthermore, the sample was based on the names of ACBSP champions as reported publicly, so if the name of the champion changed, some qualified program leaders may have been inadvertently left out of the sample frame. In addition, program leaders who were interested in the topic of innovation may have been more likely to complete the survey, resulting in a sampling bias. Finally, program leadership self-reported their perceptions about how innovation is being taught in their programs, and they may have incomplete information about the curriculum that is taught, especially if they are not the ones teaching the courses.

\section{Future Research}

Not surprisingly, the limitations provide possibilities for additional research. This article does not suggest that there is a one size fits all approach to teaching innovation education in MBA programs. More needs to be understood about the specific innovation education that is being used in MBA programs. Case study research of various business schools and programs at a variety of institutions could be performed to identify their processes for designing, implementing, and evaluating innovation education curriculum. In the present study, data was collected through surveys of MBA program leadership, which offered the perspective that was needed to answer the research questions. Other forms of data collection such as inclass observations of how innovation education is being implemented, or content analysis of innovation education syllabi, would add additional perspectives to the research questions.

While assessment is a critical component of teaching and learning, there is criticism that business education programs are not assessing the new pedagogies they are introducing into their curricula (Mayhew, Selznick, Zhang et al., 2019). Existing literature on curricula that uses experiential learning and projectbased learning in business education tends to focus on summative assessment, such as completing a specific task that results in deliverables such as a written report or group presentation (Bacon, 2005). Future research focused on summative assessment in courses that focus on teaching innovation would benefit business students, faculty, and program leadership, and add to the body of knowledge surrounding innovation education.

Future research is also needed to understand the specific student learning outcomes and topics in innovation curriculum in business schools and programs. Although business schools and programs have begun focusing on innovation education, "little is known about the content and process of innovation education" (Kars-Unluogla, 2016, p. 1). Mars (2013) suggested that one essential objective of an innovation course should be that "students develop a deep and broad understanding of the role of innovation in fostering economic growth, bettering society, and improving/enhancing the human condition" (p. 121). Content analysis of existing innovation curricula would uncover commonalities and differences in student learning outcomes, curriculum topics, methods, and instructional approaches. Observational research in classrooms that teach innovation topics would lend new ideas to the growing field of innovation education.

\section{CONCLUSION}

It is important to distinguish between innovative management education and management education that has curricular approaches to teaching the knowledge and skills to help students innovate in business (Ivanova, 2016). There is a lack of understanding about the content, process, effective teaching methods, and instructional strategies used in innovation education in business schools and programs. The present study investigated, through the perceptions of MBA program leaders, how business schools and programs are teaching students skills in innovation. Curriculum is foundational to the teaching and learning process, and is a key concern for stakeholders such as professors, deans and other administrators, educational policymakers, industry professionals, and government (Khan \& Law, 2015). Findings showed that MBA programs are offering innovation education but it is limited to courses, and not entire concentrations; MBA 
programs are using experiential learning approaches to teach innovation; and, communication and collaboration were identified as the the top instructional strategies. MBA programs should consider developing coursework focused on innovation education, and should consider using design thinking to enhance students' innovation skills. The 4Cs outlined in the Partnership for 21st Century Skills, the theoretical framework for the study, should be explicitly taught within the MBA curriculum. Since innovation is a key way of differentiating products and services and building competitive advantage in our rapidly changing, 21st century business environment, MBA students need to be equipped with innovation skills, meaning not only understanding what innovation is, but having the ability to be innovative.

\section{REFERENCES}

AACSB International. (2010). Business schools on an innovation mission. AACSB International, Inc. Retrieved from https://www.aacsb.edu/ /media/AACSB/Publications/research-reports/businessschools-on-an-innovationmission.ashx\#: : text=Innovation\%20is\%20as\%20much\%20about, is\%20about\%20science\%20an $\mathrm{d} \% 20$ technology.\&text=Business $\% 20$ schools $\% 20$ have $\% 20$ the $\% 20$ capacity, can $\% 20$ enable $\% 20$ su $\mathrm{ch} \% 20 \mathrm{a} \% 20$ transformation

Accreditation Council for Business Schools and Programs (ACBSP). (n.d.). ACBSP unified standards and criteria for demonstrating excellence in business programs. Retrieved from https://acbsp.org/page/accreditation-type-graduate

Alstete, J.W., \& Beutell, N.J. (2016). Balancing instructional techniques and delivery formats in capstone business strategy courses. Quality Assurance in Education, 24(2), 173-193.

Association to Advance Collegiate Schools of Business (AACSB). (2020, July 28). 2020 Guiding principles and standards for business accreditation. Retrieved from https://www.aacsb.edu//media/aacsb/docs/accreditation/business/standards-and tables/2020\%20business\%20accreditation\%20standards.ashx?la=en\&hash=E4B7D8348A6860B3 AA9804567F02C68960281DA2

Association to Advance Collegiate Schools of Business (AACSB). (2013). Eligibility procedures and accreditation standards for business accreditation, adopted April 8, 2013. Retrieved from http://www.aacsb.edu/ /media/AACSB/Docs/Accreditation/Standards/2013-businessstandards.

Athaide, G.A., \& Desai, H.B. (2005). Design and implementation of an interdisciplinary marketing/management course on technology and innovation management. Journal of Marketing Education, 27(3), 239-249. https://doi.org/10.1177/0273475305279529

Bacon, D.R. (2005). The effect of group projects on content-related learning. Journal of Management Education, 29(2), 248-267.

Baumol, W.J., \& Strom, R.J. (2007). Entrepreneurship and economic growth. Strategic Entrepreneurship Journal, 1(3-4), 233-237.

Berdan, S.N. (2012). Top skills MBA grads need for success. Huffpost. Retrieved from http://www.huffingtonpost.com/stacie-nevadomski-berdan/mba-jobs-_b_1126299.html

Bhardwaj, G., Crocker, A., Sims, J., \& Wang, R.D. (2018). Alleviating the plunging-in bias, elevating strategic problem solving. Academy of Management Learning and Education, 17(3), 279-301.

Biffi, A., Bissola, R., \& Imperatori, B. (2017). Chasing innovation: A pilot case study of a rhizomatic design thinking education program. Education \& Training, 59(9), 957-977. doi:10.1108/ET-012016-0007

Bisman, J. (2011). Engaged pedagogy: A study of the use of reflective journals in accounting education. Assessment and Evaluation in Higher Education, 36(3), 315-330.

Brill, R., Gilfoil, D., \& Doll, K. (2014). Exploring predictability of instructor ratings using a quantitative tool for evaluating soft skills among MBA students. American Journal of Business Education, $7(3), 175-182$.

Bruner, J.S. (1966). Toward a theory of instruction. Belkapp Press. 
Burgelman, R.A., Maidique, M.A., \& Wheelwright, S.C. (1996). Strategic management of technology and innovation (Vol. 2). Irwin.

Christensen, C. (1997). The innovator's dilemma: When new technologies cause great firms to fail. Harvard Business Press.

Cobo, C. (2013). Skills for innovation: Envisioning an education that prepares for the changing world. Curriculum Journal, 24(1), 67-85. https://doi.org/10.1080/09585176.2012.744330

Cooperrider, D. (2008). Sustainable innovation. BizEd, 7(4), 32-38.

Cousens, A., Goffin, K., Mitchell, R., van der Hoven, C., \& Szwejczewski, M. (2009). Teaching new product development using the 'CityCar' simulation. Creativity and Innovation Management, 18, 176-189.

Datar, S., Garvin, D., \& Cullen, P. (2011). Rethinking the MBA: Business education at a crossroads. Journal of Management Development, 30(5), 451-462.

Dewey, J. (1929). The quest for certainty: A study of the relation of knowledge and action. Minton Balch and Company.

Dewey, J. (1938). Experience and education. Simon and Schuster.

Drucker, P.F. (1985). Innovation and entrepreneurship. Harper \& Row.

Dubinsky, J. (2006). The role of reflection in service-learning. Business and Professional Communication Quarterly, 69(3), 306-311.

Duffy, T.M., \& Cunningham, D.J. (1996). Constructivism: Implications for the design and delivery of instruction. In D.H. Jonassen (Ed.), Handbook of research for educational communications and technology (pp. 170-98). Macmillan.

Eason, C., Mazzei, M., \& Service, R. (2019). Teaching and doing strategy as an intentional strategic innovation mindset. Journal of Strategic Innovation and Sustainability, 14(4), 26-43.

Enarson, H., \& Drucker, P. (1960). Innovation in higher education. The Journal of Higher Education, 31(9), 495-501.

Fagerberg, J., Mowery, D.C., \& Nelson, R.R. (Eds.). (2005). Oxford handbook of innovation. Oxford University Press.

Fischer, T., Dietz, J., \& Antonakis, J. (2017). Leadership process models: A review and synthesis. Journal of Management, 43(6), 1727-1753.

Fish, L.A., \& Kim, J. (2013). Creating an innovative and entrepreneurial collegiate academic program. In L.V. Shavinana (Ed.), The Routledge international handbook of innovation education (pp. 473481). Routledge. https://doi.org/10.4324/9780203387146

Foster, J., \& Yaoyuneyong, G. (2016). Teaching innovation: Equipping students to overcome real-world challenges. Higher Education Pedagogies, 1(1), 42-56. https://doi.org/10.1080/23752696.2015.1134195

Friedman, H.H. (2017). Is higher education making students dumb and dumber? Available at SSRN 3014350 .

Gall, M.D., Gall, J.P., \& Borg, W.R. (2007). Educational research: An introduction (8th Ed.). Allyn and Bacon

Gardner, H. (1983). Frames of mind: The theory of multiple intelligences. Basic Books.

Glassman, A.M., \& Opengart, R. (2016). Teaching innovation and creativity: Turning theory into practice. Journal of International Business Education, 11, 113.

Glen, R., Suciu, C., \& Baughn, C. (2014). The need for design thinking in business schools. Academy of Management Learning \& Education, 13(4), 653-667.

Grennon-Brooks, J., \& Brooks, M.G. (1999). In search of understanding: The case for constructivist classrooms. Association for Supervision and Curriculum Development.

Gupta, A., \& Bennett, S. (2014). An empirical analysis of the effect of MBA programs on organizational success. The International Journal of Educational Management, 28. Doi:10.1108/IJEM-10-20120114 
Howard, T., Datar, S., Garvin, D., \& Cullen, P. (2011). Rethinking the MBA: Business education at a crossroads. The Journal of Management Development, 30(5), 451-462.

https://doi.org/10.1108/02621711111132966

Ivanova, O. (2016). Management education for innovation: Developing a study course to improve innovation capacity of MBA students. Dissertation study. University of Barcelona.

Iyengar, R. (2015). MBA: The soft and hard skills that matter. IUP Journal of Soft Skills, 9(1), 7-14.

Kars-Unluoglu, S. (2016). How do we educate future innovation managers? Insights on innovation education in MBA syllabi. Innovation, 18(1), 74-98.

Khan, M.A., \& Law, L.S. (2015). An integrative approach to curriculum development in higher education in the USA: A theoretical framework. International Education Studies, 8(3), 66-76. doi:10.5539/ies.v8n3p66

Kivunja, C. (2014). Innovative pedagogies in higher education to become effective teachers of 21 st century skills: Unpacking the learning and innovations skills domain of the new learning paradigm. International Journal of Higher Education, 3(4), 37-48.

Kolb, D. (1984). Experiential learning: Experience as the source of learning and development. Englewood Cliffs. Prentice Hall.

Larry, H., \& Sakkab, N. (2006). Connect and develop: Inside Procter \& Gamble's new model for innovation. Harvard Business Review, 84(3), 58-67.

Levy, F., \& Murnane, R.J. (2004). The new division of labor: How computers are creating the next job market. Princeton University Press.

Mabry, J.B. (1998). Pedagogical variations in service-learning and student outcomes: How time, contact and reflection matter. Michigan Journal of Community Service Learning, 5, 32-47.

Maritz, A., \& Donovan, J. (2015). Entrepreneurship and innovation. Education+ Training.

Maritz, A., De Waal, A., Buse, S., Herstatt, C., Lassen, A., \& Maclachlan, R. (2014). Innovation education programs: Toward a conceptual framework. European Journal of Innovation Management, 17(2), 166-182. https://doi.org/10.1108/EJIM-06-2013-0051

Mars, M.M. (2013). Building toward a holistic model of innovation and entrepreneurship education: Transformation before commercialization. Advances in The Study of Entrepreneurship, Innovation, and Economic Growth, 23, 113-124.

Mayhew, M.J., Simonoff, J.S., Baumol, W.J., Wiesenfeld, B.M., \& Klein, M.W. (2012). Exploring innovative entrepreneurship and its ties to higher educational experiences. Research in Higher Education, 53(8), 831-859.

Mirela, B. (2008). Innovation-the characteristic tool of entrepreneurs. Economic Science Series, 17(4), $135-138$.

Navarro, P. (2008). The MBA core curricula of top-ranked US business schools: A study in failure? Academy of Management Learning \& Education, 7(1), 108-123.

Neo, M., \& Neo, T.K. (2009). Engaging students in multimedia-mediated constructivist learningStudents' perceptions. Educational Technology \& Society, 12(2), 254-66.

O'Sullivan, D. (2003). Online project based learning in innovation management. Education \& Training, 45(2), 110. http://dx.doi.org/10.1108/00400910310464080

P 21. (2014). Learning for the 21 st century: A report and MILE guide for 21 st century skills. Retrieved from http://www.21stcenturyskills.org

Partnership for 21st Century Skills (P21). (2011). Framework for 21st century learning. The Partnership for $21^{\text {st }}$ Century Learning. Retrieved from http://www.P21.org

Partnership for 21st Century Skills. (2015). P21 framework definitions. The Partnership for 21st Century Learning. Retrieved from http://www.P21.org

Plattner, H. (2010). Bootcamp bootleg. Design School Stanford.

Porter, L.W., \& McKibbin, L.E. (1988). Management education and development: Drift or thrust into the $21^{\text {st }}$ century. McGraw-Hill.

Priem, R.L. (2018). Toward becoming a complete teacher of strategic management. Academy of Management Learning \& Education, 17(3), 374-388. https://doi.org/10.5465/amle.2017.0237

84 Journal of Higher Education Theory and Practice Vol. 21(5) 2021 
Razzouk, R., \& Shute, V. (2012). What is design thinking and why is it important? Review of Educational Research, 82(3), 330-348.

Secretary's Commission on Achieving Necessary Skills. (1991). What work requires of schools. U.S. Department of Labor.

Segon, M., \& Booth, C. (2012). Are MBAs meeting business's needs. World Journal of Management, $4(2), 1-13$

Seidel, V.P., Marion, T.P., \& Fixson, S.K. (2020) Innovating how to learn design thinking, making, and innovation: Incorporating multiple modes in teaching the innovation process. INFORMS Transactions on Education, 20(2), 73-84. https://doi.org/10.1287/ited.2019.0220

Shaheen, N., Ahmad, N., \& Hussain, S. (2019). Learning entrepreneurship: A study of instructional practices in business education and entrepreneurial skills of business graduates in Pakistan. Global Regional Review, 4(4), 122-129.

Shuayto, N. (2013). Management skills desired by business school deans and employers: An empirical investigation. Business Education \& Accreditation, 5(2), 93-105.

Stock, K.L., Bucar, B., \& Vokoun, J. (2018). Walking in another's shoes: Enhancing experiential learning through design thinking. Management Teaching Review, 3(3), 221-228. https://doi.org/10.1177/2379298117736283

Sullivan, R. (2011). Business schools and the innovation conundrum. Journal of Management Development, 30(5), 492-498.

Tamim, S.R., \& Grant, M.M. (2013). Definitions and uses: Case study of teachers implementing projectbased learning. Interdisciplinary Journal of Problem-Based Learning, 7(2). https://doi.org/10.7771/1541-5015.1323

Tanyel, F., Mitchell, M.A., \& McAlum, H.G. (1999). The skill set for success of new business school graduates: Do prospective employers and university faculty agree? Journal of Education for Business, pp. 33-37.

Thomas, H. (2014). Securing the future of management education: Competitive destruction or constructive innovation? Emerald Publishing.

Thomas, J.W. (2000). A review of PBL. Retrieved from http://www.bie.org/ research/study/review_of_project_based_learning_2000/

Thursby, M.C. (2005). Introducing technology entrepreneurship to graduate education: An integrative approach. Advances in the study of Entrepreneurship, Innovation and Economic Growth, 16, 211240.

Top MBA. (2016, November 8). What innovation in business education looks like. Retrieved January 14, 2021, from https://www.topmba.com/mba-programs/what-innovation-business-education-looks

Trilling, B.F., \& Fadel, C.C (2009). 21st century skills, learning for life in our times. Jossey-Bass.

Vardis, H., \& Selden, G.L. (2013). A report card on innovation: How companies and business schools are dealing with it. Journal of Executive Education, 7(1), 2.

Vygotsky, L.S. (1978). Mind in society: The development of higher psychological processes. Harvard University Press.

West, R.E., Tateishi, I., Wright, G.A., \& Fonoimoana, M. (2012). Innovation 101: Promoting undergraduate innovation through a two-day boot camp. Creativity Research Journal, 24(2-3), 243-251.

Winter, J., Neal, J.C., \& Waner, K.K. (2005). Student teams learning to cope with conflict. The Delta Pi Epsilon Journal, 47(2), 67-74. 


\section{APPENDIX}

\section{TABLE 1 \\ MBA PROGRAM ENROLLMENT OF SURVEY RESPONDENTS}

\begin{tabular}{lll}
\hline Answer & $\mathrm{n}$ & $\%$ \\
\hline More than 500 & 4 & 22.22 \\
201-500 & 3 & 16.67 \\
Less than 200 & 11 & 61.11 \\
\hline Total & 18 & 100.00 \\
\hline
\end{tabular}

TABLE 2

RELEVANT SURVEY QUESTIONS

Questions

Does your university's MBA program have at least one course specifically devoted to teaching about innovation? (Yes, No, I Don't Know)

Collaboration/Does your university's MBA program offer a concentration/certificate/emphasis (12 credits or more) in innovation?

The Accreditation Council of Business Schools and Programs defines innovation as making meaningful change to improve programs, services, and processes that create new value for students and stakeholders. Given that definition, in what ways do your university's MBA students learn about innovation/how to innovate in their coursework? (Brainstorming; Collaboration/working with others, Communication with other; Creative thinking exercises; Design thinking; Empathy; Experimentation; Independent decisionmaking; Individual reflection; Initiative (ability to accomplish tasks independently); Inventing something new; Solving hypothetical problems; Solving real-world problems; Utilizing higher-order thinking skills; Trial and error; select all that apply)

Is the topic of innovation explicitly integrated into your required course: (Accounting; Entrepreneurship; Economics; Finance; Law/Regulatory; Management; Marketing; Organizational Behavior; Strategy/Strategic Management; Technology; Quantitative Research Techniques; Yes, No, I Don't Know, Our program doesn't have this course)

Principles of design thinking to teach innovation are used in at least one of our MBA courses. (Yes, No, I Don't Know)

Is your MBA program: (Full-time, Part-time)

Of the following list of teaching methods, rank the top three methods your MBA program is using to teach the skill of innovation. Put a 1 in the box of the top method, a 2 in the box for the second method, and a 3 in the box of the third method. (Case studies; Design thinking processes; Experiential learning; Individual project-based learning that is hypothetical; Individual project-based learning with a real organization; Guest speaker(s); Lecture; Online discussion forums; Readings from textbooks (books designed for classroom use); Readings from journals; Readings from management books that are used in industry; Service-learning; Simulations; Team project-based learning that is hypothetical; Team project-based learning with a real organization; Watching videos)

Approximately how many students are currently enrolled in your MBA program? (More than 500; 401500; 301-400; 201-300; 101-200; Fewer than 100) 
TABLE 3

COURSES WITH TOPIC OF INNOVATION MOST EXPLICITLY INTEGRATED

\begin{tabular}{lllll}
\hline \multirow{2}{*}{ Course } & \multicolumn{2}{c}{ Yes } & \multicolumn{2}{c}{ No } \\
\cline { 2 - 5 } & $\mathrm{n}$ & $\%$ & $\mathrm{n}$ & $\%$ \\
\hline Entrepreneurship & 13 & 92.86 & 1 & 7.14 \\
Marketing & 12 & 80.00 & 3 & 20.00 \\
Strategy/Strategic Management & 12 & 80.00 & 3 & 20.00 \\
Technology & 8 & 80.00 & 2 & 20.00 \\
Management & 12 & 75.00 & 4 & 25.00 \\
Organizational Behavior & 9 & 75.00 & 3 & 25.00 \\
Finance & 5 & 35.71 & 9 & 64.29 \\
Law/Regulatory & 3 & 33.33 & 6 & 66.67 \\
Quantitative Research Techniques & 2 & 33.33 & 4 & 66.67 \\
Economics & 2 & 22.22 & 7 & 77.78 \\
Accounting & 3 & 20.00 & 12 & 80.00 \\
\hline
\end{tabular}

Note: Percentage is based on number of responses per course.

TABLE 4 INNOVATION INSTRUCTION STRATEGIES USED IN COURSEWORK

\begin{tabular}{lll}
\hline Strategy & $\mathrm{n}$ & $\%$ \\
\hline Communication with others & 19 & 10.67 \\
Collaboration/working with others & 17 & 9.55 \\
Independent decision-making & 16 & 8.99 \\
Solving hypothetical problems & 16 & 8.99 \\
Solving real-world problems & 15 & 8.43 \\
Individual reflection & 14 & 7.87 \\
Brainstorming & 13 & 7.30 \\
Utilizing higher-order thinking skills & 13 & 7.30 \\
Creative thinking exercises & 11 & 6.18 \\
Initiative (ability to accomplish tasks independently) & 11 & 6.18 \\
Design thinking & 9 & 5.06 \\
Inventing something new & 7 & 3.93 \\
Empathy & 6 & 3.37 \\
Experimentation & 6 & 3.37 \\
Trial and error & 5 & 2.81 \\
\hline Total & 178 & 100 \\
\hline
\end{tabular}


TABLE 5

METHODS USED TO TEACH THE SKILL OF INNOVATION

\begin{tabular}{lll}
\hline Method & $\mathrm{n}$ & $\%$ \\
\hline Experiential learning & 4 & 23.53 \\
Team project-based learning with a real organization & 4 & 23.53 \\
Case studies & 2 & 11.78 \\
Individual project-based learning with a real organization & 1 & 5.88 \\
Lecture & 1 & 5.88 \\
Online discussion forums & 1 & 5.88 \\
Individual project-based learning that is hypothetical & 1 & 5.88 \\
Simulations & 1 & 5.88 \\
Team project-based learning that is hypothetical & 1 & 5.88 \\
Readings from textbooks (books designed for classroom use) & 1 & 5.88 \\
Total & 17 & 100.00 \\
\hline
\end{tabular}

TABLE 6

USE OF DESIGN THINKING TO TEACH INNOVATION

\begin{tabular}{lll}
\hline Design Thinking & $\mathrm{n}$ & $\%$ \\
\hline Yes & 10 & 52.63 \\
No & 4 & 21.05 \\
Not Sure & 5 & 26.32 \\
Total & 19 & 100.00 \\
\hline
\end{tabular}

